\title{
OBITUARIES
}

\section{Sir John Graham Kerr, F.R.S.}

SIR JohN GrahaM KERR, regius professor of zoology in the University of Glasgow during 1902-35 and member of Parliament for the Scottish Universities during 1935-50, died at his home, Dalny Veed, Barley, Hertfordshire, on Easter Day, after a long failing in health. By his death, at the age of eightyseven, zoology loses one of its few remaining links with the closing years of the past century, and an outstanding personality.

Born on September 18, 1869, he was the son of James Kerr, principal of Hoogly College, Calcutta. He received his early education in the parish school at Dalkeith, Midlothian, and at the Royal High School, Edinburgh, and proceeded to the study of medicine in the University of Edinburgh. By a turn of circumstance, his orientation to zoology was determined when - at the age of nineteen - he joined as naturalist an Argentine expedition which was setting out to explore the Pilcomayo River on the boundary between the Argentine and Paraguay. On this expedition (1889-91) he was engaged on general natural history and especially ornithology. The expedition's boat had to be left in the upper reaches of the river and he saved only part of his collections. At this early stage in his zoological career, Graham Kerr proved himself to be not only an observer and naturalist of great ability, but also a man of resource, courage and endurance beyond the ordinary. He was always reticent about the hardships that beset the ill-fated party on the Pilcomayo, and the part he played in averting disaster ; and his account of this famous expedition-"A Naturalist in the Gran Chaco"-was only published in 1950 .

After his return, Graham Kerr entered Christ's College, Cambridge, as a Scholar. He was a brilliant student and obtained first-class honours in Part II of the Natural Sciences Tripos when he had already published notable work on the avifauna of the Pilcomayo and on the anatomy of the pearly nautilus. Becoming a morphologist and embryologist, as so many zoologists were at the time, he was struck by the need for more knowledge of the embryology of primitive living vertebrates. Having heard of the occurrence of the dipnoan Lepidosiren in the swamps of the Paraguayan Chaco, and remembering that on the Pilcomayo he had heard of a fish which he now thought might be Lepidosiren, he planned a second expedition to investigate the habits of this littleknown lung-fish and to collect embryological material. On this expedition he was accompanied by J. S. Budgett. Large collections of Lepidosiren were made and brought home.

Graham Kerr now became demonstrator in animal morphology at Cambridge and was elected a Fellow of Christ's College and awarded the Walsingham Medal in 1898. He left Cambridge in 1902, to succeed Prof. John Young on the latter's resignation from the regius chair of natural history in Glasgow. At that time the chair included zoology and geology; however, these were separated in the following year, and Graham Kerr became the first regius professor of zoology - a post he held for thirty-three years.

Both at Cambridge and Glasgow, the South American collections formed the subject of the greater part of the research work which he and, at Glasgow, the school of workers carried out. The whole series of papers, on many aspects of dipnoan embryology, forms a corpus of research scarcely paralleled in the study of any other vertebrate. Graham Kerr's outlook was morphological and phylogenetic, and he hoped from the study of Lepidosiren as a primitive bony fish to get evidence of the evolution of the Amphibia. Throughout his work he was impressed by the very great resemblances between the embryology he was studying and that of the Amphibia, and he came to the conclusion that the Amphibia were derived from the Dipnoi. In this many present-day zoologists, on other, mainly palæontological, evidence, do not agree with hins: the embryology he described is thought to be general to the primitive bony fishes, and the Amphibia to have evolved from a related group of these fishes, the Crossopterygians. However this may be, there can be no doubt that the work of Graham Kerr and his school must be regarded as a classical example of long-continued research into a fundamental problem of zoology, and one that has greatly advanced our knowledge of the evolution of the vertebrates.

His output of zoological research was by no means restricted to the embryology of Lepidosiren. $\mathrm{He}$ published papers on the cephalopod Spirula and many other zoological subjects. His "Text Book of Embryology" appeared in 1919. By the publication of this comprehensive treatise, which dealt with all the vertebrate groups except mammals and also very fully with many important principles of biological philosophy, Kerr rendered a great service to scientific gtudents. The work was, however, unfortunate in its timing, as he was unable to deal with the expansion of experimental embryology into the vertebrate field, already pioneered by Spemann but not sufficiently established to demand attention of all embryologists; this was not to come until the late twenties. A few years later there appeared his widely used "Zoology for Medical Students" ; this was followed by a third volume, "Evolution". All Graham Kerr's books were remarkable for the clarity with which he expressed himself and for the excellence of his illustrations and style.

'Throughout his professorship he gave much time to the organization of medical teaching. He personally shouldered a great part of the work demanded by a very large medical school. His lectures were always lucid and stimulating, and those who came under his influence could not fail to be impressed with his almost encyclopædic knowledge. Graham Kerr's interests extended beyond the fields of academic zoology, for above all he was a born naturalist with a genuine love of animals-and it was these qualities that leavened his lectures and gave a wider vision to generations of medical and zoological students, many of whom now hold important posts in various parts of the world.

Graham Kerr never spared any pains to help his colleagues and assistants. He was quick to discover and encourage unsuspected abilities, and his personal influence inspired younger members of his staff with the confidence needed for the development of research interests on lines different from his own. To all he set an exacting standard in industry and efficiency, and an example in the proper use of opportunities. When he was not himself lecturing or demonstrating, a locked door secured his research from interruption. At a knock, this barrier would be opened a few 
inches only, and a face-wearing a somewhat forbidding or even ferocious expression-would appear in the chink. Then, once admitted, the intruder would be welcomed with that old-world courtesy and charm of character that all his friends will remember with affection.

When Graham Kerr first went to Glasgow, the department was poorly housed; and the monumental new building, completed in 1923, stands as his fitting memorial. Not the least of his contributions to Gilasgow zoology was the development of the departmental museum. In addition to his scientific knowledge, he had a keen artistic appreciation of display technique, and his arrangement of exhibits against a matt-black background under indirect lighting was a new and highly successful departure from tradition. This museum was Graham Kerr's especial pride, and under his inspiration it soon became one of the finest zoological museums in Britain. Among other treasures collected by Graham Kerr in South America, it contains the fang of a gigantic extinct opisthoglyph snake, Bothrodon pridii-known only from this specimen-which he loved to show to visitors.

Outside his department, Graham Kerr gave much time to the University and City of Glasgow. He served on the University Court during 1913-21 ; and was associated with the governing bodies of the Royal Technical College, the Andersonian College of Medicine, and the Royal Infirmary. He was also very active, almost throughout his time at Glasgow, in encouraging the development of the Marine Laboratory of the Scottish Marine Biological Associa. tion, at Millport. For several years he was president of the Royal Philosophical Society of Glasgow and of the Royal Physical Society of Edinburgh. During these years he received many honours. He was elected a Fellow of the Royal Society in 1909, later serving on its Council, and as vice-president in 1938. He was successively a Fellow, Neill prizeman and vice-president of the Royal Society of Edinburgh. Both Fdinburgh and St. Andrews conferred upon him the degree of LL.D. He was knighted in 1939.

No notice of Graham Kerr's achievements would be complete without reference to a subject that was near to his heart and which, in a letter to me, he once described as "an important little bit of history". In the summmer of 1895 , when present at the opening of the Kiel Canal on board Mr. W. B. Hardy's yacht Raven, he had been impressed by the fact that France and Germany had adopted means to diminish the conspicuousness of their warships, while the British ships still wore black paint with yellow funnels. Combining, as he did, a professional interest in the methods of camouflage used by Nature and practical experience of their working with a special interest in warships, Graham Kerr worked out a system of camouflage based upon the principles of obliterative shading and disruption ('dazzle'), and in September 1914 urged their adoption upon the Admiralty. His proposals were promulgated to the fleet on November 10, 1914. Unfortunately, some of the earlier experiments with paint were at fault-the work being left to the discretion of individual officers who sometimes failed to appreciate the optical principles involved; and Graham Kerr continued to urge the need for $a_{0}$ special department to deal with naval camouflage under expert supervision. There were further delays, but between 1917 and the end of the War upwards of five thousand ships were treated. In initiating this work he rendered a major public service.
Graham Kerr had a high sense of public duty, and for many years took a leading part in the Unionist Party in Scotland. $\mathrm{He}$ became successively chairman of the Glasgow Committee of Scottish Universities Unionists and of the Glasgow Unionist Association. In 1934 he was elected president of the Scottish Unionist Association, and the following year became member of Parliament for the Scottish Universities in succession to the late Lord Tweedsmuir on the latter's appointment as Governor-General of Canada.

After his retirement from public affairs his sight began to fail, and his last years were saddened by his blindness. This he endured-as he had endured the hardships of the Chaco wilderness - with fortitude. To friends who visited him at Barley he showed a quiet stoicism and self-forgetfulness, and he was ever ready to enliven conversation with a shrewd comment or amusing anecdote. He once jokingly referred to the report, published in Nature, of his award of the Linnean Gold Medal in 1955 , as "a very pleasant obituary notice". 'This remark was characteristic of Sir John, for he always seemed to regard the many honours that were conferred upon him with amused modesty-half-feigned and half-serious.

Sir John Graham Kerr married Elizabeth Mary, daughter of Thomas Kerr, in 1903. Mrs. Graham Kerr died in 1934. In 1936 he married Isobel, daughter of A. Dunn Macindoe and widow of Dr. Alan E. Clapperton. Sir John is survived by Lady Graham Kerr and by two sons and a daughter of the first marriage.

Hugh B. CotT

\section{Dr. J. F. S. Stone}

DR. J. F. S. Stone, whose untimely death has recently been announced, was well known for his contributions to the prehistoric archæology of Britain, and in particular of Wessex and of the Salisbury area, in which he lived and worked. Stone carried out a number of excavations near his home, am ong which those on Easton Down, the sites of prehistoric flint mines and their associated settlements, were particularly noteworthy. But he will be remembered chiefly for his application of scientific techniques to the elucidation of problems concerned with broader fields of prehistoric study: notably he co-operated with Dr. F. S. Wallis and others in the systematic petrological examination of large numbers of prehistoric stone axes, as a result of which it was possible to demonstrate widespread trade in Neolithic times, and again with the late Mr. H. C. Beck and latterly with Mr. L. C. Thomas in the examination of fazence beads, by means of which he was able to throw light on the relations between the higher civilizations of the East Mediterranean and Bronze Age Britain.

Stone was an amateur in the sense that he put far more into prehistory than he ever took out of it; but his contributions were of a professional calibre. This was due to the fact that he was able to combine a feeling for archæology and history with a precise training in the natural sciences. He was essentially a modest man, and never made the mistake of exaggerating the potentialities of the scientific techniques which he brought to bear upon the problems of prehistoric archæology; for this reason his influence was wholly for the good, and it may be hoped that his example may attract other scientists into a field which is in the deepest sense rewarding. J. G. D. Clark 